\title{
PEMAHAMAN ORANG TUA MENGENAI DAMPAK PLAYGROUP DALAM PERKEMBANGAN ANAK USIA DINI DI KOTA PALANGKA RAYA
}

\author{
Dewi Rosaria Indah ${ }^{1} \&$ Rusmaladewi $^{1}$ \\ ${ }^{1}$ Program Studi PG PAUD FKIP Universitas Palangka Raya \\ Jl. H. Timang Komplek Kampus Tunjung Nyaho Palangka Raya \\ Email : dewirosariaindah5@gmail.com
}

\begin{abstract}
ABSTRAK
Playgroup adalah salah satu bentuk layanan pendidikan bagi anak usia tiga sampai enam tahun yang berfungsi untuk meletakkan dasar-dasar ke arah perkembangan, sikap, pengetahuan dan keterampilan yang di perlukan bagi anak usia dini dalam menyesuaikan diri dengan lingkungannya dan untuk pertumbuhan serta perkembangan selanjutnya, sehingga siap memasuki pendidikan dasar (Direktorat Paud, Menu Pembelajaran Generik, 2002 : 3). Rentang usia anak yang bersekolah di Playgroup yakni usia 2-4 tahun. Dengan bermain, anak akan belajar mengenal aturan, disiplin, tanggung jawab, dan kemandirian serta belajar menyesuaikan diri dengan lingkungannya. Di tahun 2019 ini yang terdata di Dinas Pendidikan Kota Palangka Raya ada sekitar 218 lembaga PAUD (Negeri maupun Swasta). Penelitian ini bertujuan Untuk mengetahui pemahaman orang tua mengenai dampak Playgroup dalam perkembangan anak usia dini di Kota Palangka Raya. Instrumen dalam penelitian ini berupa kuesioner untuk mengukur Pemahaman Orang Tua Mengenai Dampak Playgroup Dalam Perkembangan Anak Usia Dini. Jenis pernyataan kuesioner yaitu pernyataan tertutup menggunakan skala likert yang nantinya akan memberikan respon yang tegas. Sebelum dilakukan uji validitas jumlah kuesioner 35 pernyataan dan setelah dilakukan uji validitas didapatkan 24 pernyataan yang dinyatakan valid dan 11 pernyataan yang dinyatakan tidak valid. Adapun sampel data dalam penelitian ini adalah orang tua murid yang berjumlah 50 orang. Dalam penelitian ini, peneliti akan menggunakan statistik deskriptif dengan rumus persentase. Berdasarkan data hasil penelitian telah diperoleh skor keseluruhan dari angket yang telah dijawab oleh orang tua di beberapa lembaga KB Kota Palangka Raya adalah sebesar 3972 dari skor yang di harapkan 5.472, dimana dari skor tersebut memperoleh persentase sebesar 72,58\%. Sehingga dapat di golongkan dalam kategori Baik.
\end{abstract}

Kata kunci : Pemahaman orang tua, Playgroup, AUD 


\section{PENDAHULUAN}

Pemahaman merupakan proses pengetahuan seseorang dalam mencari makna atau memahami suatu hal yang belum diketahui oleh dirinya yang berkaitan dengan segala sesuatu yang ada. Oleh karena itu pencapaian tingkat pemahaman seseorang akan berbeda pula sesuai dengan tingkat pengetahuan seseorang. Pemahaman merupakan sesuatu proses kemampuan pengetahuan untuk memahami.

Playgroup adalah salah satu bentuk layanan pendidikan bagi anak usia tiga sampai enam tahun yang berfungsi untuk meletakkan dasar-dasar ke arah perkembangan, sikap, pengetahuan dan keterampilan yang di perlukan bagi anak usia dini dalam menyesuaikan diri dengan lingkungannya dan untuk pertumbuhan serta perkembangan selanjutnya, sehingga siap memasuki pendidikan dasar (Direktorat Paud, Menu Pembelajaran Generik, 2002 : 3). Orang tua adalah ayah dan ibu dari anak-anak, baik melalui hubungan biologis maupun sosial. Umumnya orang tua memiliki peranan yang sangat penting dalam membesarkan anak. Orang tua merupakan orang dewasa yang membawa anak kedewasa, terutama dalam masa perkembangan.

Tugas orang tua melengkapi dan mempersiapkan anak menuju ke kedewasaan dengan memberikan bimbingan dan pengarahan yang dapat membantu anak dalam menjalani kehidupan. Didalam keluarga orang tualah yang bertanggung jawab dalam suatu keluarga atau rumah tangga, dan sudah selayaknya apabila orang tuamencurahkan perhatian dan bimbingan untuk mendidik anak, supaya anak tersebut memperoleh dasardasar dan pola pergaulan hidup pendidikan yang baik dan benar, melalui penanaman disiplin dan kebebasan secara serasi. Peranan keluarga menggambarkan seperangkat perilaku interpersonal, sifat, kegiatan yang berhubungan dengan individu dalam posisi pada situasi tertentu. Peranan individu dalam keluarga didasari oleh harapan dan pola perilaku dari keluarga, kelompok dan masyarakat.

.Playgroup adalah suatu tempat dimana anak dapat mengembangkan beberapa kemampuan dasarnya seperti kemampuan motorik kasar dan halus, mengembangkan kemandirian, bersosialisasi, berbahasa dan berkomunikasi, mengenal kehidupan beragama, ketrampilan dll. Di harapkan dengan anak mengikuti kegiatan di Playgroup ini tumbuh kembangnya menjadi optimal sampai sebelum ia memasuki pendidikan dasar. 
Jadi kesimpulannya adalah, Playgroup atau yang juga dikenal PAUD (Pendidikan Anak Usia Dini) merupakan kelompok bermain pada satuan pendidikan anak usia dini. Anak-anak yang bersekolah di Playgroup biasanya akan bersekolah setengah hari saja. Namun, ada pula beberapa Playgroup yang menyelenggarakan pendidikan lebih dari setengah hari. Playgroup seperti ini kebanyakan siswanya berasal dari keluarga dengan kedua orang tua bekerja. Sehingga rutinitas anak dari pagi hingga sore hari sampai di jemput orang tuanya di lakukan di sekolah. Para staf Playgroup akan mendampingi anak dalam bermain, belajar, tidur siang, dan lain-lain. Rentang usia anak yang bersekolah di Playgroup yakni usia 2-4 tahun. Dengan bermain, anak akan belajar mengenal aturan, disiplin, tanggung jawab, dan kemandirian serta belajar menyesuaikan diri dengan lingkungannya. Terlebih, di usia ini anak-anak sudah bisa mengikuti kegiatan di kelompok bermain dan taman kanak-kanak.

Dengan belajar sambil bermain, maka secara otomatis daya pikir, imajinasi, emosi, dan sosialnya akan terstimulasi. Di situ, terbuka kesempatan bagi anak untuk menciptakan karya-karya nyata dengan kemampuannya sendiri. Ia akan mengalami banyak hal sendiri, berkomunikasi aktif dengan teman-temannya, dan mengekspresikan pengalamannya baik secara lisan maupun gambar/tulisan. Idealnya anak masuk ke Playgroup yaitu pada usia 2-4 tahun. Fungsi kelompok bermain menurut Direktorat Pendidikan Anak Usia Dini (2001 : 2) adalah "Sebagai salah satu bentuk pendidikan prasekolah dengan mengutamakan kegiatan bermain dengan menerapkan sistem bermain sambil belajar secara individual dan kelompok melalui kegiatan aktif".

Kelompok bermain menurut BPKB Jayagiri (1994, : 13) merupakan wahana pembinaan anak usia 3 - 6 tahun yang memiliki fungsi sebagai berikut:

a. Pengganti sementara peranan orang tua dalam mendidik anaknya. Pada saat ini di mana orang tua sibuk termasuk ibu maka mereka menyerahkan pendidikan anaknya pada kelompok bermain, karena kelompok bermain merupakan kegiatan yang terorganisir sehingga dapat membantu pertumbuhan dan perkembangan anak.

b. Sebagai tempat kegiatan bermain bagi anak usia $3-6$ tahun. Kegiatan bermain di lakukan secara bersama-sama atau berkelompok di bawah bimbingan atau pengawasan pengasuh yang memahami sifat, karakter, kebutuhan dan menguasai teknis bermain bagi anak $3-6$ tahun. Kelompok bermain merupakan tempat 
bermain bagi anak yang merasa kesepian dan jenuh di rumah sendirian, karena anak merasa perlu mempunyai teman yang dapat di ajak bermain dalam suasana gembira.

c. Sebagai lembaga pendidikan prasekolah untuk mempersiapkan anak memasuki pendidikan selanjutnya. Diharapkan pada lembaga pendidikan prasekolah seperti kelompok bermain, anak terbiasa berhadapan dengan lingkungan pergaulan yang lebih luas di luar lingkungan keluarga. Hal ini mengakibatkan anak-anak yang mengikuti pendidikan pada kelompok bermain lebih siap menyesuaikan diri dalam mengikuti pendidikan selanjutnya.

d. Membantu perkembangan anak secara menyeluruh. Pada kelompok bermain, anak diberikan sejumlah stimulasi dalam rangka pengembangan kognitif, psikomotorik, afektif dan sosial.

\section{A. Dampak positif dari play gruop :}

Pendidikan untuk anak usia dini yang berkualitas baik akan membawa dampak positif bagi perkembangan anak secara keseluruhan, antara lain pada:

1. Perkembangan Sosial dan emosional

Dengan memasukkan anak ke Playgroup atau TK, Ibu bisa membantunya dalam menjalin hubungan dengan orang yang lebih dewasa serta teman-teman atau anak-anak lainnya. Anak yang sudah merasa nyaman dengan orang-orang di sekitarnya kemungkinan besar mau berpartisipasi dalam proses pembelajaran dan aktifitas serta permainan seperti bermain peran.

2. Perkembangan Kognitif

Playgroup atau TK yang baik memiliki kurikulum yang tepat, yang membuat anak lebih bisa mengembangkan kemampuan kognitif tertentu.

3. Perkembangan Bahasa

Perkembangan bahasa anak terjadi sangat cepat saat anak berumur 1-5 tahun. Anak merasa aman dan nyaman dengan lingkungannya dan orang-orang di sekitarnya akan lebih mudah berinteraksi dan melakukan percakapan. Interaksi yang dilakukan sehari-hari itu bisa berujung pada kemampuan bahasa yang lebih tinggi lagi. Kemampuan bahasa itu bisa di tingkatkan dengan melakukan diskusi kelompok, menyanyi, dan membaca dengan keras misalnya. Jadi, 
menyekolahkan anak pada Playgroup dan TK bisa menjadi investasi terendiri bagi perkembangan kecerdasan anak.

4. Bagi anak-anak yang sudah matang secara emosional dan usianya sudah memadai, Playgroup akan membantunya belajar dengan skala yang lebih luas.

Playgroup mempersiapkan anak masuk ke dunia yang lebih luas, yaitu sekolah dasar (SD). Memasuki SD bagi anak kecil merupakan sebuah pengalaman yang luar biasa. Ia akan melihat dan bertemu dengan orang yang lebih banyak lagi. "Bahkan, istilahnya, ia harus menghafal pintu kelas.

5. Anak usia dini penuh kreativas dan bakat. Buktinya ada anak menang dalam lomba puisi dan melukis.

Anak Usia Dini sekarang mendapatkan fasilitas yang memadai (khususnya di kota-kota). Sehingga mereka dapat mengembangkan bakat dan kemampuan yang di milikinya. Contoh fasilitas bermain dan alat musik di sekolahnya.

6. Pada Anak Usia Dini saat ini sudah di perkenalkan dan di ajarkan mahir berbahasa Inggris, sehingga tak heran mereka sudah pandai berbahasa Inggris.

Pada Anak Usia Dini distimulus untuk cepat mengerti. Terutama dengan kurikulum sekolah saat ini yang fokus terhadap perkembangan intelegensi anak.

B. Dampak negatif dari Playgroup :

1. Dari sebuah sumber dikatakan bahwa salah satu Playgroup ada yang mematok harga sekitar 750 ribu sebulan. Jadi ini berdampak pada kondisi keuangan orangtua si anak.

2. Meski secara teori banyak manfaat positif yang bisa dipetik anak di kelompok bermain, Jacinta mengingatkan para orangtua akan dampak negatifnya. Yakni, bertemunya anak dengan teman-teman yang berlatar belakang "wawasan" berbeda.

3. Menurut banyak penelitian, anak yang terlalu muda bersekolah, mungkin saja bisa mengikuti pelajaran tapi seringkali memiliki masalah dalam perkembangan emosi dan sosialnya kelak.

4. Memasukkan sekolah anak terlalu dini, sama seperti menyemai benih kanker. Kita tidak tahu kapan kanker akan muncul dan dalam jenis apa. Otaknya belum siap. Kita tidak pernah tahu kapan ia kehilangan motivasi belajar. Semakin muda kita sekolahkan anak, semakin cepat pula ia mengalami BLAST (Bored Lonely 
Afraid-Angry Stress Tired). Anak yang mengalami BLAST, lebih rentan menjadi pelaku dan korban bullying, pornografi \& kejahatan seksual.

5. Ilmu yang kita miliki untuk mengasuh pun serba tanggung. Ilmu yang setengahtengah, berujung pada false belief (keyakinan yang salah). Sayangnya false belief ini dapat berubah menjadi societal false belief (keyakinan yang salah pada sekelompok orang). Jika orangtua tidak memiliki kemampuan berpikir (thinking skill) yang baik, false belief akibat ilmu yang serba tanggung itu jadi pembenaran bersama atas keputusan kita yang keliru.

6. Anak Usia Dini di paksakan untuk mengetahui belajar banyak hal, sehingga anak kehilangan waktu bermain. Padahal usia anak masih hidup di dalam dunia bermain. Hal ini berdampak kelak ketika dewasa dia akan memuaskan bermain karena dulu tidak sempat.

7. Anak Usia Dini cenderung manja dan tidak mandiri, karena segala kebutuhannya terpenuhi dengan mudah dan anak selalu mengharapkan bantuan orang lain.

8. Di sekolah Anak Usia Dini di ajarkan cenderung di ajarkan yang berbau modern sehingga di khawatirkan mereka melupakan budaya tradisional bangsanya.

9. Anak terlalu fokus kepada prestasi dan intelegensi sehingga terkadang anakanak lupa bersosialisasi dengan orang sekitar.

Berdasarkan data tersebut, untuk mengetahui pemahaman orang tua mengenai dampak playgroup dalam perkembangan anak usia dini kota Palangka Raya, dapat dihitung dengan rumus sebagai berikut :

$$
\mathrm{P}=\frac{\mathrm{F}}{\mathrm{N}} \times 100 \%
$$

Keterangan :

$\mathrm{P}=$ Persentase

$\mathrm{F}=$ Frekuensi yang sedang dicari persentasenya

$\mathrm{N}=$ Jumlah frekuensi

Berdasarkan data-data tesebut dapat dinyatakan bahwa :

a) $\mathrm{F}=$ Total perolehan hasil pengetahuan orang tua yakni sebesar 3581

b) $\mathrm{N}=$ Total dari hasil maksimal ( $4 \mathrm{x}$ jumlah responden $\mathrm{x}$ jumlah item penyataan) yang diharapkan yakni sebesar 5.400)

Sehingga berdasarkan data-data tersebut akan diperoleh perhitungan sebagai berikut : 


$$
P=\frac{\mathbf{3 9 7 2}}{\mathbf{5 4 7 2}} \times 100 \%=72,58 \%
$$

Berdasarkan data hasil penelitian telah diperoleh skor keseluruhan dari angket yang telah dijawab oleh orang tua di beberapa lembaga KB Kota Palangka Raya adalah sebesar 3972 dari skor yang di harapkan 5.472, dimana dari skor tersebut memperoleh persentase sebesar 72,58\%. Sehingga dapat di golongkan dalam kategori Baik.

\section{METODE PENELITIAN}

Jenis penelitian ini merupakan penelitian deskriptif Kuantitatif. Menurut Sukardi (2003:157). Penelitian deskriptif merupakan metode penelitian yang berusaha menggambarkan dan menginterpretasi objek sesuai dengan apa adanya. Penelitian dilaksanakan di beberapa lembaga Playgroup yang ada di kota Palangka Raya.

Populasi dalam penelitian ini adalah lembaga Playgroup yang berada dikota Palangka Raya. Adapun sampel data dalam penelitian ini adalah orang tua murid yang berjumlah 50 orang. Instrumen dalam penelitian ini berupa kuesioner untuk mengukur Pemahaman Orang Tua Mengenai Dampak Playgroup Dalam Perkembangan Anak Usia Dini. Jenis pernyataan kuesioner yaitu pernyataan tertutup menggunakan skala likert yang nantinya akan memberikan respon yang tegas. Sebelum dilakukan uji validitas jumlah kuesioner 35 pernyataan dan setelah dilakukan uji validitas didapatkan 24 pernyataan yang dinyatakan valid dan 11 pernyataan yang dinyatakan tidak valid.

Pilihan jawaban kuesioner terdiri dari sangat setuju, setuju, tidak setuju, sangat tidak setuju. Responden yang menjawab pertanyaan benar bernilai 4 dan menjawab salah bernilai 1. Responden akan dikategori memiliki pengetahuan sesuai dengan (Arikunto 2010 dalam Fitrisari 2016) menjadi baik jika mampu menjawab benar dengan prosentase nilai $76-100 \%$, cukup jika mampu menjawab benar dengan prosentase nilai $60-75 \%$ dan kurang jika mampu menjawab benar dengan prosentase nilai <60. Berikut adalah kisi-kisi kuesioner yang digunakan untuk mengumpulkan data 
Tabel 1. Kisi-kisi kuesioner Pemahaman Orang Tua Mengenai Dampak Playgroup Dalam Perkembangan AUD

\begin{tabular}{|c|c|c|c|c|}
\hline \multirow[t]{2}{*}{ Variabel } & \multirow[t]{2}{*}{ Indikator } & \multicolumn{2}{|c|}{ No Item } & \multirow[t]{2}{*}{ Jumlah } \\
\hline & & Favourabel & Unfavourabel & \\
\hline \multirow{17}{*}{$\begin{array}{l}\text { Pemahaman } \\
\text { Orang Tua } \\
\text { Mengenai } \\
\text { Dampak } \\
\text { Playgroup } \\
\text { Dalam } \\
\text { Perkembangan } \\
\text { Anak Usia } \\
\text { Dini }\end{array}$} & a. Perkembangan Bahasa & $7,11,13,19$ & & 4 \\
\hline & $\begin{array}{l}\text { b. Potensi (Kognitif, } \\
\text { Motorik, Sosial) }\end{array}$ & $10,12,24,35$ & & 4 \\
\hline & c. Pengalaman Sosial & 6,22 & & 2 \\
\hline & $\begin{array}{l}\text { d. Perkembangan } \\
\text { Emosional }\end{array}$ & 2,23 & & 2 \\
\hline & e. Kedisipilinan & 26,34 & & 2 \\
\hline & f. Kemandirian & 3,5 & & 2 \\
\hline & $\begin{array}{l}\text { g. Perkembangan } \\
\text { Kognitif }\end{array}$ & $14,17,21,27$ & & 5 \\
\hline & h. Kreatifitas & 16,20 & & 2 \\
\hline & $\begin{array}{l}\text { i. Usia wajar masuk } \\
\text { Playgroup }\end{array}$ & 1 & 28 & 2 \\
\hline & $\begin{array}{l}\text { j. Kesiapan menuju } \\
\text { jenjang lebih tinggi }\end{array}$ & 29,31 & & 2 \\
\hline & k. Durasi jam sekolah & 30 & & 1 \\
\hline & 1. Bored-Kebosanan & 25,32 & & 2 \\
\hline & m. Lonely-Kesepian & 15 & & 1 \\
\hline & $\begin{array}{c}\text { n. Afraid-Angry } \\
\text { (Ketakutan- } \\
\text { Kemarahan) }\end{array}$ & 4,8 & & 2 \\
\hline & o. Stress-Stres & 33,9 & & 2 \\
\hline & p. Tired-Kelelahan & 18 & & 1 \\
\hline & Total Item & & & 35 \\
\hline
\end{tabular}

Dalam penelitian ini, peneliti akan menggunakan statistik deskriptif dengan rumus persentase untuk mengetahui pemahaman orang tua mengenai dampak playgroup dalam perkembangan anak usia dini kota Palangka Raya. Adapun rumusnya adalah sebagai berikut :

$$
P=\frac{F}{N} \times 100 \%
$$

KotaPalangka Raya terdiri dari 5 (lima) kecamatan diantaranya Kecamatan Pahandut, Kecamatan Jekan Raya, Kecamatan Sebangau, Kecamatan Bukit Batu, dan Kecamatan Rakumpit. Data jumlah peserta didik Lembaga PAUD di 5 kecamatan di Kota Palangka Raya terdapat dalam tabel dibawah ini: 
Tabel 2. Data Jumlah Lembaga PAUD Kota Palangka Raya

DATA JUMLAH LEMBAGA PAUD KOTA PALANGKA RAYA

$\begin{array}{clllll}\text { Nama } & \text { TK/RA } & \text { KB } & \text { TPA } & \text { SPS } & \text { Jumlah }\end{array}$

\section{Kecamatan}

Pahandut

2 Kecamatan Jekan

45

11

4

Raya

3 Kecamatan

83

24

3

111

Sebangau

4 Kecamatan Bukit

12

5

18

Batu

5 Kecamatan

Rakumpit

Jumlah

161

43

$\begin{array}{lll}7- & 218\end{array}$

Tabel 3. Data Jumlah Kelompok Bermain (Playgroup) Kota Palangka Raya

No

Data Jumlah Playgroup Kota Palangka Raya

1 Kecamatan Pahandut

11

2 Kecamatan Jekan Raya

24

3 Kecamatan Sebangau

5

4 Kecamatan Bukit Batu

5 Kecamatan Rakumpit

3

Jumlah

\section{HASIL DAN PEMBAHASAN}

Dinas Pendidikan Kota Palangka Raya terus melakukan pembinaan kepada PAUD dan Pendidikan Formal yang terdapat di 5 kecamatan di wilayah Kota Palangka Raya. Dimana setiap kecamatan ada 7 lembaga PAUD Negeri seperti di kecamatan Pahandut dengan jumlah peserta didik 788 anak, kecamatan Jekan Raya 1.232 anak, kecamatan Sebangau sebanyak 220 anak, kecamatan Bukit Batu sebanyak 75 anak dan kecamatan Rakumpit siswa didik relatif sedikit dengan total siswa didik PAUD sebanyak 2.315 anak.

Uji validitas telah dilakukan pada 30 responden, di PAUD Pembina Kota Palangka Raya pada tanggal 20-21 Agustus 2018. Pada uji instumen ini peneliti menggunakan bantuan SPSS windows 20. Hasil uji validitas pada instrumen pengetahuan orang tua tentang pendidikan seks pada anak terdapat 24 item pertanyaan 
yang valid yaitu nomor $1,2,3,4,5,6,7,8,9,11,12,15,16,17,18,22,23,25,26,30$, $31,32,33,34$, dan terdapat 11 item pertanyaan yang tidak valid yaitu nomor 10, 13, 14, 19, 20, 21, 24, 27, 28, 29, 35 Item pertanyaan yang tidak valid, tidak dilakukan revisi karena pertanyaan yang valid sudah mewakili penelitian yang akan dilakukan. Sehingga didapatkan 24 item pertanyaan untuk instrumen pengetahuan orang tua tentang pendidikan seks pada anak. Uji reliabilitas ini diperoleh hasil uji koesioner pengetahuan orang tua tentang pendidikan seks pada anak dengan menggunakan Alpha Cronbach's dikatakan reliabel jika nilai $\mathrm{r} \geq 0,6$ (Arikunto 2010, dalam Fitisari 2016). Hasil uji reliabel sebesar 0,697 sehingga kuisioner ini dinyatakan reliabel.

\begin{tabular}{cr}
\hline \multicolumn{2}{c}{ Reliability Statistics } \\
\hline Cronbach's Alpha & N of Items \\
\hline .697 & 24 \\
\hline
\end{tabular}

\section{Hasil Pernyataan Setiap Indikator}

Berdasarkan yang sudah peneliti jelaskan di bab sebelumnya bahwa teknik pengumpulan data adalah dengan melakukan penyebaran angket kepada orang tua khususnya kepada ibu yang memiliki anak berusia 2,5 - 4 tahun di 6 (enam) Lembaga PAUD di Kota Palangka Raya yang memiliki layanan Playgroup sebanyak 57 responden. Dengan jumlah pernyataan sebanyak 24 butir soal yang harus dijawab oleh responden.

Untuk selanjutnya peneliti menyajikan hasil perhitungan persentase pengetahuan orang tua tiap indikator berdasarkan hasil angket yang dilakukan melalui pemaparan sebagai berikut:

Tabel 4. Hasil Jawaban Per-Sub Indikator A

\begin{tabular}{lllllll}
\hline \multicolumn{1}{c}{$\begin{array}{c}\text { Indikator (Sub } \\
\text { Indikator) }\end{array}$} & \multicolumn{1}{c}{ Pernyataan } & SS & S & TS & STS & Total \\
\hline $\begin{array}{l}\text { Dampak Positif } \\
\text { Perkembangan } \\
\text { Bahasa) }\end{array}$ & $\begin{array}{l}\text { Kemampuan berbahasa anak } \\
\text { saya semakin baik semenjak } \\
\text { bersekolah }\end{array}$ & 18 & 23 & 15 & 1 & 57 \\
\hline & Persentase & $\mathbf{3 2 \%}$ & $\mathbf{4 0 \%}$ & $\mathbf{2 6 \%}$ & $\mathbf{2 \%}$ & $\mathbf{1 0 0 \%}$ \\
\hline & $\begin{array}{l}\text { Anak saya mampu } \\
\text { berkomunikasi dengan teman } \\
\text { sebaya dan gurunya }\end{array}$ & 9 & 28 & 19 & 1 & 57 \\
\hline Persentase & & $\mathbf{1 6 \%}$ & $\mathbf{5 0 \%}$ & $\mathbf{2 6 \%}$ & $\mathbf{1 \%}$ & $\mathbf{1 0 0 \%}$ \\
& & & & & & \\
\end{tabular}


Tabel 5. Hasil Jawaban Per-Sub Indikator B

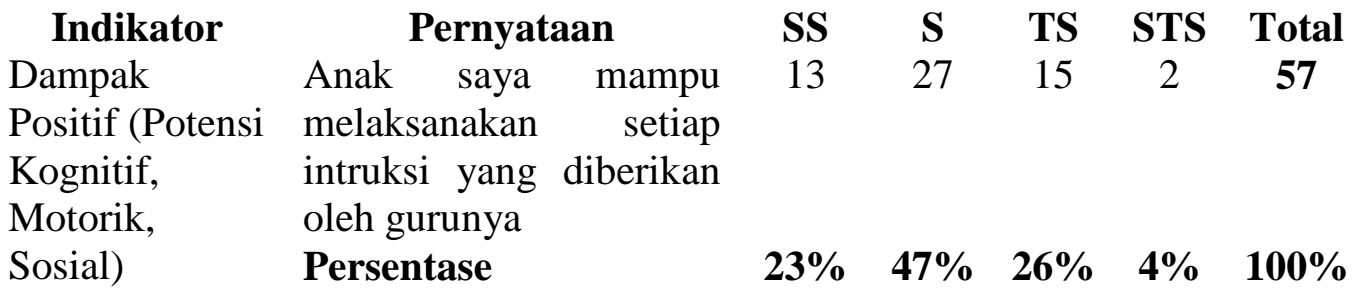

\section{Tabel 6. Hasil Jawaban Per-Sub Indikator C}

\begin{tabular}{|c|c|c|c|c|c|c|}
\hline Indikator & Pernyataan & SS & $\mathbf{S}$ & TS & STS & Total \\
\hline \multirow{13}{*}{$\begin{array}{l}\text { Dampak positif } \\
\text { (Pengalaman } \\
\text { Sosial)-Sub I }\end{array}$} & melihat & 37 & 20 & - & - & 57 \\
\hline & anak & & & & & \\
\hline & memiliki banyak & & & & & \\
\hline & teman di sekolah & & & & & \\
\hline & Persentase & $65 \%$ & $35 \%$ & - & - & $100 \%$ \\
\hline & Anak & 10 & 6 & 24 & 17 & 57 \\
\hline & mampu & & & & & \\
\hline & menyesuaikan & & & & & \\
\hline & dirinya $\quad$ di & & & & & \\
\hline & lingkungan & & & & & \\
\hline & sekolahnya yang & & & & & \\
\hline & baru & & & & & \\
\hline & Persentase & $17 \%$ & $11 \%$ & $42 \%$ & $30 \%$ & $100 \%$ \\
\hline
\end{tabular}

Tabel 7. Hasil Jawaban Per-Sub indikator D

Indikator

Dampak positif (Perkembangan emosional)

\begin{tabular}{lccccc}
\multicolumn{1}{c}{$\begin{array}{c}\text { Pernyataan } \\
\text { Anak saya }\end{array}$} & 14 & 34 & 8 & 1 & $\mathbf{5 7}$ \\
$\begin{array}{l}\text { tampak antusias } \\
\text { di kelas }\end{array}$ & & & & & \\
\hline Persentase & $\mathbf{2 5 \%}$ & $\mathbf{6 0 \%}$ & $\mathbf{1 4 \%}$ & $\mathbf{1 \%}$ & $\mathbf{1 0 0 \%}$ \\
\hline $\begin{array}{l}\text { Ketika } \\
\text { disekolah anak }\end{array}$ & 10 & 32 & 14 & 1 & $\mathbf{5 7}$ \\
$\begin{array}{l}\text { saya mampu } \\
\text { mengontrol } \\
\text { emosinya } \\
\text { dengan baik }\end{array}$ & & & & & \\
\hline $\begin{array}{l}\text { Persentase } \\
\mathbf{1 7 \%}\end{array}$ & $\mathbf{5 6 \%}$ & $\mathbf{2 4 \%}$ & $\mathbf{1 \%}$ & $\mathbf{1 0 0 \%}$
\end{tabular}


Tabel 8. Hasil Jawaban Per-Sub Indikator E

Indikator

Dampak positif

(Kedisiplinan)

\section{Indikator \\ Dampak positif (Kemandirian)}

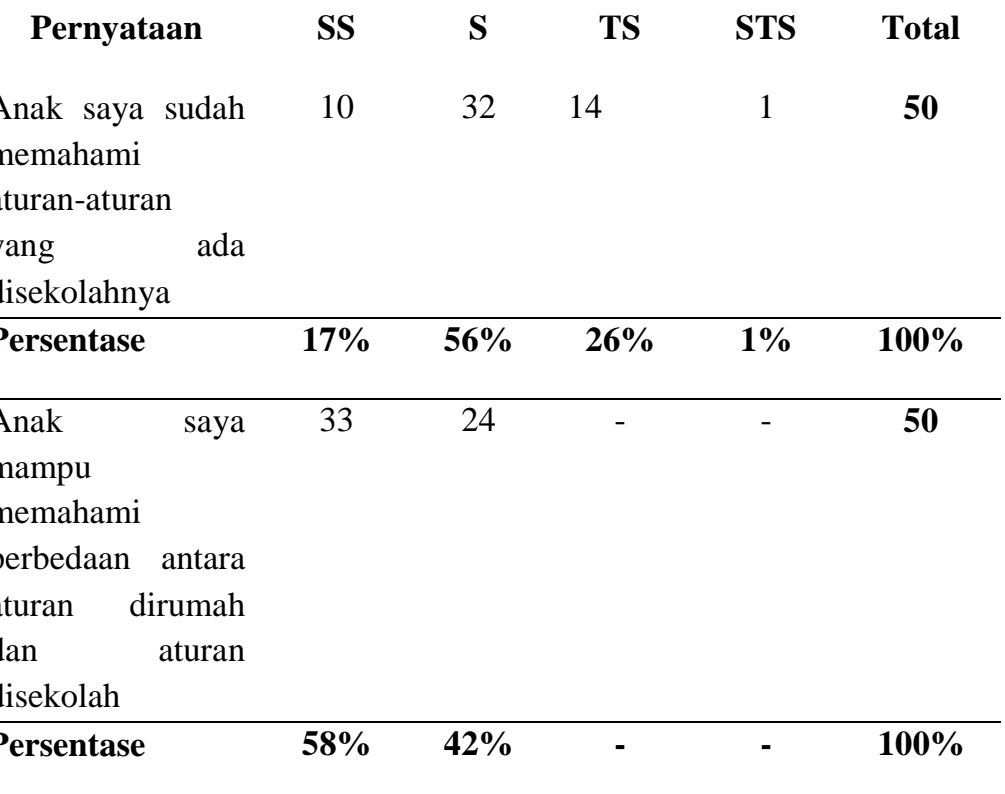

Tabel 9. Hasil Jawaban Per-Sub Indikator F

\begin{tabular}{|c|c|c|c|c|c|}
\hline Pernyataan & SS & $\mathbf{S}$ & TS & STS & Total \\
\hline $\begin{array}{lr}\text { Sejak anak saya } \\
\text { masuk playgroup, ia } \\
\text { nampak } \\
\text { mandiri }\end{array}$ & 40 & 17 & - & - & 57 \\
\hline Persentase & $70 \%$ & $30 \%$ & - & - & $100 \%$ \\
\hline $\begin{array}{lrr}\text { Anak saya } & \text { sudah } \\
\text { tahu jam } & \text { masuk } \\
\text { sekolah dan } & \text { selalu } \\
\text { siap ketika } & \text { akan } \\
\text { bersekolah } & \end{array}$ & - & 26 & 10 & 21 & 57 \\
\hline Persentase & - & $45 \%$ & $17 \%$ & $38 \%$ & $100 \%$ \\
\hline
\end{tabular}

\section{Tabel 10. Hasil Jawaban Per-Sub Indikator G}

Indikator

Dampak positif (Perkembangan Kognitif)

\begin{tabular}{lccccc}
\multicolumn{1}{c}{ Pernyataan } & SS & S & TS & STS & Total \\
$\begin{array}{l}\text { Anak saya kini } \\
\text { mampu mengenal } \\
\text { angk adan huruf } \\
\text { awal (permulaan) }\end{array}$ & & 32 & 5 & - & $\mathbf{5 0}$ \\
\hline Persentase & $\mathbf{3 5 \%}$ & $\mathbf{5 6 \%}$ & $\mathbf{9 \%}$ & - & $\mathbf{1 0 0 \%}$ \\
\hline
\end{tabular}


Tabel 11. Hasil Jawaban Per-Sub Indikator $\mathbf{H}$

\begin{tabular}{lllllll} 
Indikator & \multicolumn{1}{c}{ Pernyataan } & SS & S & TS & STS & Total \\
$\begin{array}{l}\text { Dampak positif } \\
\text { (Kreatifitas) }\end{array}$ & $\begin{array}{l}\text { Semenjak bersekolah, } \\
\text { anak saya mampu } \\
\text { mengekspresikan } \\
\text { dirinya dengan bebas }\end{array}$ & & 34 & 3 & - & $\mathbf{5 7}$ \\
& Persentase & $\mathbf{3 5 \%}$ & $\mathbf{5 9 \%}$ & $\mathbf{6 \%}$ & - & $\mathbf{1 0 0 \%}$
\end{tabular}

Tabel 12. Hasil Jawaban Per-Sub Indikator I

\begin{tabular}{lllllll} 
Indikator & \multicolumn{1}{c}{ Pernyataan } & SS & S & TS & STS & Total \\
$\begin{array}{ll}\text { Dampak positif (Usia } \\
\begin{array}{l}\text { wajar masuk } \\
\text { playgroup) }\end{array}\end{array}$ & $\begin{array}{l}\text { Saya mengetahui } \\
\text { usia minimal anak }\end{array}$ & 18 & 36 & 3 & - & $\mathbf{5 7}$ \\
& $\begin{array}{l}\text { yang seharusnya } \\
\text { masuk playgroup }\end{array}$ & & & & \\
& Persentase & $\mathbf{3 2 \%}$ & $\mathbf{6 3 \%}$ & $\mathbf{5 \%}$ & $\mathbf{2 -}$ & $\mathbf{1 0 0 \%}$ \\
\hline
\end{tabular}

Tabel 13. Hasil Jawaban Per-Sub Indikator J

\begin{tabular}{|c|c|c|c|c|c|c|}
\hline Indikator & Pernyataan & SS & $\mathbf{S}$ & TS & STS & Total \\
\hline \multirow[t]{4}{*}{$\begin{array}{l}\text { Dampak positif } \\
\text { (Kesiapan menuju } \\
\text { jenjang lebih } \\
\text { tinggi) }\end{array}$} & $\begin{array}{l}\text { Saya merasa kelas } \\
\text { playgroup dapat } \\
\text { mengenalkan dasar- } \\
\text { dasar belajar formal } \\
\text { kepada anak saya }\end{array}$ & 38 & 17 & 2 & - & 57 \\
\hline & Persentase & $67 \%$ & $33 \%$ & $4 \%$ & - & $100 \%$ \\
\hline & $\begin{array}{l}\text { Dengan bersekolah } \\
\text { anak saya mampu } \\
\text { memfokuskan } \\
\text { perhatiannya dengan } \\
\text { baik }\end{array}$ & 35 & 10 & 5 & 7 & 57 \\
\hline & Persentase & $61 \%$ & $17 \%$ & $8 \%$ & $14 \%$ & $100 \%$ \\
\hline
\end{tabular}

\section{Tabel 14. Hasil Jawaban Per-Sub Indikator K}

Indikator

Dampak positif

(Durasi Jam

Sekolah)

\begin{tabular}{lccccc}
\multicolumn{1}{c}{ Pernyataan } & SS & S & TS & STS & Total \\
$\begin{array}{l}\text { Durasi belajar anak } \\
\text { saya disekolah }\end{array}$ & 34 & 21 & - & 2 & $\mathbf{5 7}$ \\
maksimal 2 jam & & & & & \\
\hline Persentase & $\mathbf{5 9 \%}$ & $\mathbf{3 6 \%}$ & - & $\mathbf{5 \%}$ & $\mathbf{1 0 0 \%}$ \\
\hline
\end{tabular}




\section{Tabel 15. Hasil Jawaban Per-Sub Indikator L}

Indikator

Dampak negatif

(Bored-

Kebosanan)

Pernyataan
ak saya nampak
ekan dan jenuh
gan aktifitas di

sekolah

\begin{tabular}{|c|c|c|c|c|c|}
\hline Persentase & - & - & $44 \%$ & $56 \%$ & $100 \%$ \\
\hline $\begin{array}{l}\text { Anak saya Nampak } \\
\text { bosan dan banyak } \\
\text { melakukan kegiatan } \\
\text { lain diluar intruksi } \\
\text { gurunya }\end{array}$ & - & - & 20 & 37 & 57 \\
\hline Persentase & & & $35 \%$ & $65 \%$ & $100 \%$ \\
\hline
\end{tabular}

\section{Tabel 16. Hasil Jawaban Per-Sub Indikator M}

Indikator

Dampak negative (Lonely-Kesepian)

\begin{tabular}{lccccc}
\multicolumn{1}{c}{ Pernyataan } & SS & S & TS & STS & Total \\
$\begin{array}{l}\text { Di sekolah anak } \\
\text { saya terlihat tidak } \\
\text { menyukai suasana } \\
\text { kelas beserta teman } \\
\text { dan gurunya }\end{array}$ & 1 & 5 & 19 & 32 & \\
\hline Persentase & $\mathbf{1 \%}$ & $\mathbf{8 \%}$ & $\mathbf{3 4 \%}$ & $\mathbf{5 7 \%}$ & $\mathbf{1 0 0 \%}$
\end{tabular}

\section{Tabel 17. Hasil Jawaban Per-Sub Indikator N}

Indikator
Dampak negatif
(Afraid-Angry=
ketakutan-
kemarahan)

\begin{tabular}{|c|c|c|c|c|c|}
\hline Pernyataan & SS & $\mathbf{S}$ & TS & STS & Total \\
\hline $\begin{array}{l}\text { Saat pertama kali } \\
\text { masuk playgroup } \\
\text { anak saya Nampak } \\
\text { ragu-ragu }\end{array}$ & 2 & 8 & 23 & 24 & 57 \\
\hline Persentase & $4 \%$ & $14 \%$ & $40 \%$ & $42 \%$ & $100 \%$ \\
\hline $\begin{array}{lr}\text { Anak saya nampak } \\
\text { pemalu } & \text { terhadap } \\
\text { teman-teman barunya }\end{array}$ & 4 & 7 & 29 & 17 & 57 \\
\hline Persentase & $7 \%$ & $12 \%$ & $50 \%$ & $31 \%$ & $100 \%$ \\
\hline
\end{tabular}


Tabel 18. Hasil Jawaban Per-Sub Indikator O

\begin{tabular}{|c|c|c|c|c|c|c|}
\hline Indikator & Pernyataan & SS & $\mathbf{S}$ & TS & STS & Total \\
\hline \multirow[t]{4}{*}{$\begin{array}{l}\text { Dampak negatif } \\
\text { (Stress-stres) }\end{array}$} & $\begin{array}{l}\text { Setiap kali hendak } \\
\text { sekolah anak saya } \\
\text { selalu menangis }\end{array}$ & 3 & 6 & 27 & 21 & 57 \\
\hline & Persentase & $4 \%$ & $10 \%$ & $48 \%$ & $35 \%$ & $100 \%$ \\
\hline & $\begin{array}{l}\text { Anak saya nampak } \\
\text { kesulitan } \\
\text { mengendalikan } \\
\text { emosinya }\end{array}$ & 1 & 4 & 29 & 23 & 57 \\
\hline & Persentase & $2 \%$ & $7 \%$ & $50 \%$ & $41 \%$ & $100 \%$ \\
\hline
\end{tabular}

\section{Tabel 19. Hasil Jawaban Per-Sub Indikator $P$}

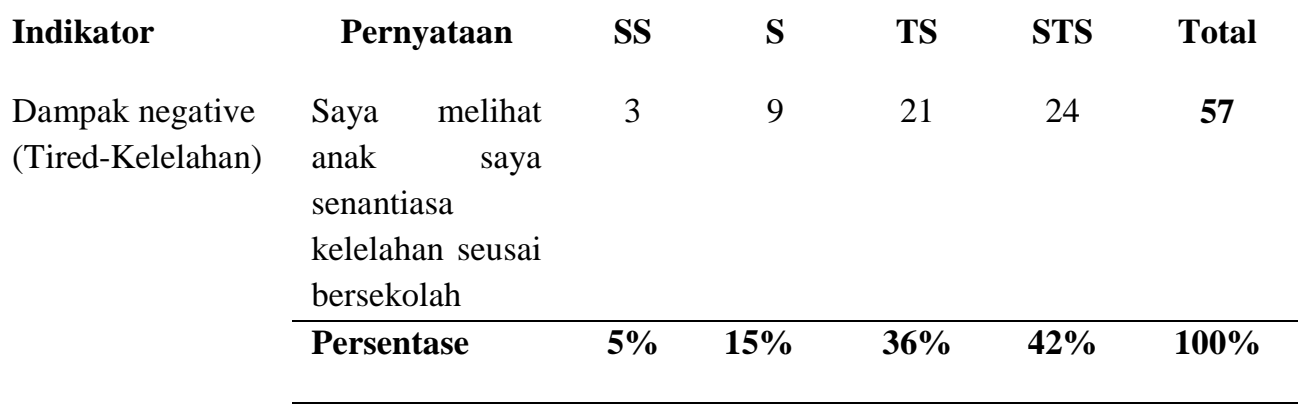

\begin{tabular}{cccc}
\hline Alternatif Jawaban & Skor Jawaban (f) & $\mathbf{f} / \mathbf{N}(\mathbf{c 3} / \mathbf{c} 7)$ & Persentase \\
\hline SS & 309 & 0,228888889 & $23 \%$ \\
\hline S & 459 & 0,34 & $34 \%$ \\
\hline TS & 431 & 0,319259259 & $32 \%$ \\
\hline STS & 151 & 0,111851852 & $11 \%$ \\
\hline Total & $\mathbf{1 3 5 0}$ & & $\mathbf{1 0 0 \%}$
\end{tabular}

1. Hasil Keselurahan Pemahaman Orang Tua

Untuk selanjutnya peneliti menyajikan hasil keseluruhan perhitungan angket pemahaman orang tua mengenai dampak playgroup dalam perkembangan anak usia dini berdasarkan setiap indikator dalam table berikut ini : 


\section{Tabel 20. Perolehan hasil keseluruhan Pemahaman Orang Tua Mengenai Dampak Playgroup Dalam Perkembangan Anak Usia Dini}

\section{Dampak Positif Playgroup}

1. Saya mengetahui usia minimal anak yang seharusnya masuk playgroup (kelompok bermain).

2. Anak saya nampak antusias saat berada dikelas.

3. Sejak anak saya masuk playgroup, ia nampak lebih mandiri.

4. Anak saya sudah tahu jam masuk sekolah dan selalu siap ketika akan bersekolah.

5. Saya melihat anak saya banyak memiliki teman di sekolah.

6. Kemampuan berbahasa anak saya semakin baik semenjak bersekolah.

7. Anak saya mampu berkomunikasi dengan teman sebaya dan

8. Anak saya mampu melaksanakan setiap instruksi yang diberikan oleh gurunya.

9. Semenjak bersekolah, anak saya mampu mengekspresikan dirinya dengan bebas.

10. Anak saya kini mampu mengenal angka dan huruf awal (permulaan).

11. Anak saya sudah memahami aturan-aturan yang ada disekolahnya.

12. Durasi belajar anak saya disekolah maksimal 2 jam.

13. Dengan bersekolah anak saya mampu memfokuskan perhatiannya dengan baik.

14. Anak saya mampu memahami perbedaan antara aturan dirumah dan aturan disekolah

\section{Dampak Negatif Playgroup}

15. Saat pertama kali masuk playgroup anak saya nampak ragu-ragu.

16. Anak saya nampak pemalu terhadap teman-teman barunya.

17. Setiap kali hendak sekolah anak saya selalu menangis.

18. Di sekolah anak saya terlihat tidak menyukai suasana kelas beserta teman dan gurunya.

19. Saya melihat anak saya senantiasa kelelahan seusai bersekolah.

20. Anak saya mampu menyesuaikan dirinya di lingkungan sekolahnya yang baru.

21. Ketika disekolah anak saya mampu mengontrol emosinya dengan baik

22. Anak saya nampak tertekan dan jenuh dengan aktifitasnya disekolah.

23. Anak saya nampak bosan dan banyak melakukan kegiatan lain diluar intruksi gurunya.

24. Anak saya nampak kesulitan dalam mengendalikan emosinya

25.

Total

Berdasarkan data tersebut, untuk mengetahui pemahaman orang tua mengenai dampak playgroup dalam perkembangan anak usia dini kota Palangka Raya, dapat dihitung dengan rumus sebagai berikut : 


$$
\mathrm{P}=\frac{\mathrm{F}}{\mathrm{N}} \times 100 \%
$$

Keterangan :

$\mathrm{P}=$ Persentase

$\mathrm{F}=$ Frekuensi yang sedang dicari persentasenya

$\mathrm{N}=$ Jumlah frekuensi

Berdasarkan data-data tesebut dapat dinyatakan bahwa :

c) $\quad \mathrm{F}=$ Total perolehan hasil pengetahuan orang tua yakni sebesar 3581

d) $\quad \mathrm{N}=$ Total dari hasil maksimal $(4 \mathrm{x}$ jumlah responden $\mathrm{x}$ jumlah item penyataan) yang diharapkan yakni sebesar 5.400)

Sehingga berdasarkan data-data tersebut akan diperoleh perhitungan sebagai berikut :

$$
\mathbf{P}=\frac{\mathbf{3 9 7 2}}{\mathbf{5 4 7 2}} \times \mathbf{1 0 0} \%=72, \mathbf{5 8} \%
$$

Berdasarkan data hasil penelitian telah diperoleh skor keseluruhan dari angket yang telah dijawab oleh orang tua di beberapa lembaga KB Kota Palangka Raya adalah sebesar 3972 dari skor yang di harapkan 5.472, dimana dari skor tersebut memperoleh persentase sebesar 72,58\%. Sehingga dapat di golongkan dalam kategori Baik.

\section{Pembahasan}

Pemahaman orang tua mengenai dampak playgroup dalam pendidikan anak usia dini Kota Palangka Raya keseluruhannya berpengetahuan baik hal ini dilihat dari cara orang tua menyikapi pendidikan untuk anak usia dini yang berkualitas baik akan membawa dampak positif bagi perkembangan anak secara keseluruhan, antara lain pada 1) Perkembangan Sosial dan emosional, 2) Perkembangan Kognitif, 3) Perkembangan Bahasa, 4) Bagi anak-anak yang sudah matang secara emosional dan usianya sudah memadai, Playgroup akan membantunya belajar dengan skala yang lebih luas., 5) Playgroup mempersiapkan anak masuk ke dunia yang lebih luas, yaitu sekolah dasar (SD). Anak usia dini penuh kreativas dan bakat. Buktinya ada anak menang dalam lomba puisi dan melukis, 6) Anak Usia Dini sekarang mendapatkan fasilitas yang memadai (khususnya di kota-kota) sehingga mereka dapat mengembangkan bakat dan kemampuan yang di milikinya. 


\section{KESIMPULAN}

Pemahaman Orang Tua Mengenai Dampak Playgroup Dalam Perkembangan Anak Usia Dini, berdasarkan data hasil penelitian telah diperoleh skor keseluruhan dari angket yang telah dijawab oleh orang tua di beberapa lembaga KB Kota Palangka Raya adalah sebesar 3972 dari skor yang di harapkan 5.472, dimana dari skor tersebut memperoleh persentase sebesar 72,58\%. Sehingga dapat di golongkan dalam kategori Baik. 


\section{DAFTAR PUSTAKA}

Arikunto, Suharsimi. 2006. Prosedur Penelitian Suatu Pendekatan Praktik. Jakarta: Rineka Cipta.

Asmawati, Luluk. 2014. Perencanaan Pembelajaran PAUD. Bandung: Remaja Rosada Karya

Aisyah, Siti. (2008). Pembelajaran Terpadu. Buku materi Pokok PGTK2501/25KS/Modul 1-6. Jakarta: Universitas Terbuka.

Kemendiknas. 2014. Pengenalan Kurikulum 2013 Pendidikan Anak Usia Dini Indonesia. Jakarta: Plt. Direktorat Pembinaan Pendidikan Anak Usia Dini.

Latif, Abdul. (2007). Pendidikan Berbasis Nilai Kemasyarakatan. Bandung: Reflika Aditama

M. Taqiyuddin. (2005). Pendidikan Untuk semua (Dasar dan Falsafah Pendidikan Luar Sekolah). Cirebon: STAIN Cirebon Press.

Nurihsan, Juntika, 2007. Perkembangan Peserta Didik, Bandung : Sekolah Pasca Sarjana UPI

Tilaar. (1992). Manajemen Pendidikan Nasional. Bandung: Rosda

Sugiyono. 2014. Metode Penelitian Kuantitatif, Kualitatif dan $R \&$ D. Alfabeta. Bandung

Wiyani \& Barnawi, Novan Ardy. 2014. Format Paud. Aruzz Media. Jogjakarta https://tuturma/waspada-ini-dampak-negatig-anak-sekolah-terlalu-dini/ https://id.theasianparent.com/10-manfaat-anak-sekolah-paud https://www.ayahbunda.co.id/balit-psikologi/haruskah-balita-masuk-playgroup3f https;//hipwee.com/list/play-group-untuk-pendidikan-anak-usia-terlalu-dini-baik-atautidak/ 